\title{
Tamoxifen Treatment in Correlation with Increased ET-1 Levels Is Associated with the Development of Breast Cancer Metastases
}

\author{
Melanie von Brandenstein ${ }^{*}$, Julia Straube ${ }^{2}$, Christina-Maria Geisbüsch ${ }^{3}$, Luka Ozretić ${ }^{4}$, \\ Yasemin Ural $^{5}$, Verena Kirn', Wolfram Malter6, Jochen W. U. Fries ${ }^{7}$ \\ ${ }^{1}$ Department of Urology, University Hospital of Koeln, Koeln, Germany \\ ${ }^{2}$ Department of Molecular and Experimental Surgery, University Hospital Erlangen, Erlangen, Germany \\ ${ }^{3}$ Department of Pediatric and Adolescent Psychiatry, Psychsomatic and Psychotherapy University \\ Clinic RTWH Aachen, Germany \\ ${ }^{4}$ Department of Cellular Pathology, Royal Free Hospital, London, UK \\ ${ }^{5}$ Department of Urology, University Hospital of Koeln, Koeln, Germany \\ ${ }^{6}$ Department of Gynecology and Obstetrics, University Hospital of Koeln, Koeln, Germany \\ ${ }^{7}$ Department of Pathology, University Hospital of Koeln, Koeln, Germany \\ Email: *melan ie@vonbrandenstein.de,Julia.straube@uk-erlan gen.de, cgeisbuesch@ukaachen.de, lozretic@t-online.de, \\ yasemin.ural@uk-koeln.de, verena.kirn@uk-koeln.de,wolfram.malter@uk-koeln.de, jochen.fries@uk-koeln.de
}

How to cite this paper: von Brandenstein, M., Straube, J., Geisbüsch, C.-M., Ozretić, L., Ural, Y., Kirn, V., Malter, W. and Fries, J.W.U. (2018) Tamoxifen Treatment in Correlation with Increased ET-1 Levels Is Associated with the Development of Breast Cancer Metastases. Journal of Cancer Therapy, 9, 438-463.

https://doi.org/10.4236/jct.2018.95038

Received: March 28, 2018

Accepted: May 21, 2018

Published: May 24, 2018

Copyright $\odot 2018$ by authors and Scientific Research Publishing Inc. This work is licensed under the Creative Commons Attribution International License (CC BY 4.0).

http://creativecommons.org/licenses/by/4.0/

cc) (i) Open Access

\begin{abstract}
Background: In breast cancer patients, a correlation between endothelin-1 (ET-1) and lymph node metastasis was found. While breast cancer with a positive ER status can be treated with Tamoxifen, several studies describe increasing Tamoxifen resistance in patients. We analyzed the relationship between Tamoxifen, ET-1 overexpression, and ER leading to Tamoxifen resistance. Methods: Breast cancer cell lines were treated with Tamoxifen, ET-1, estrogen and combinations. Using qRT-PCR, immune-precipitation, Western blot, EMSA and immunohistology target gene expression and ER complex partners were investigated. Human biopsies and mastectomy specimens were immunohistologically studied for Vimentin 3, and ERß. Results: Breast cancer cells stimulated with a combination of Tamoxifen and ET-1 downregulate $\mathrm{ER} \alpha$, while upregulating intracellular ET-1, and ERß. Immunoprecipation of nuclear extracts with ET-1, ER $\alpha$ or ERß agarose conjugated antibodies reveals a complex formation change replacing ER $\alpha$ by ERß once Tamoxifen forms a complex with ET-1. ERß and ET-1 migrate into the nucleus. ET-1 stimulation upregulates metastases promoting target genes (IL-6, Wnt11), including a novel one, Vimentin 3. Tissue analyses show Vim3 and ERß expression in metastases of $\mathrm{ER} \alpha$ positive breast cancer, and in $\mathrm{ER} \alpha$ negative biopsies/mastectomy specimens. Conclusion: We are the first to describe a complex consisting of
\end{abstract}


Tamoxifen, ERß and ET-1, whose nuclear transmigration causes an overexpression of target genes. This mechanism may explain Tamoxifen resistance. Future pathologic analyses should include estrogen beta receptor status as well as the ET-1 expression. This concept presents a new treatment approach for individualized medicine in breast cancer patients with increased ET-1 levels.

\section{Keywords}

Endothelin-1, Estrogen, Estrogen Receptors, Tamoxifen, Vimentin3

\section{Introduction}

Breast cancer is the major type of cancer that occurs in women worldwide [1]. Breast cancer is a hormone-dependent tumor. Apart from chemotherapy, a hormone-therapy is a frequently elected treatment method for patients with positive estrogen receptor status. One important drug for hormone-therapy is Tamoxifen (Tam). Tam binds to both estrogen receptors (alpha and beta) and inhibits the production of specific target genes [2], important for tumor development.

In 1966, the first description of the estrogen receptor alpha (ER $\alpha$ ) was published in human tissue [3], thirty years later than the detection of the estrogen receptor beta (ERß) [4]. Due to the fact that the $\operatorname{ER} \beta$ was analyzed 30 years later, most of the pathological institutions today analyze the breast cancer samples predominantly regarding their ER $\alpha$ levels. Is the tissue sample negative for expression of the ER $\alpha$ ? The pathologist diagnoses this breast cancer as estrogen receptor negative tumor and the patient will not be treated with Tam.

However, several different studies show that the ER $\alpha$ negative samples can be ER $\beta$ positive [2] [5] and therefore treatable with Tamoxifen (Tam). From the literature, it is known that most of the $\mathrm{ER} \beta$ positive breast cancer patients treated with Tam have a better outcome [6] [7] [8].

The biggest problem, however, is that most of the pathological institutions will not even analyze the $\operatorname{ER} \beta$ presence, since this is not required according to the gynaecological treatment guidelines, which appears in the light of the results from respective studies [6] [7] [8] ethically unacceptable.

Nevertheless, the presence of the $\operatorname{ER} \beta$ is also described in the literature with a poor outcome and increasing tamoxifen resistances [9]. Furthermore is the expression of the $\mathrm{ER} \beta$ associated with lymph node metastasis [10]. Reviewing several papers, all describing the aggressive variant of breast cancer, it is notable that Endothelin-1 (ET-1) is also associated with the aggressive variant of breast cancer [11] [12] [13].

ET-1, first described as a vasoconstrictor peptide [14], is also frequently associated with the development of tumors [15] [16] [17]. ET-1 binds via two independent receptors $\mathrm{A}$ and $\mathrm{B}$ and the expression of these receptors plays an important role in the development of tumors [18] [19] [20] [21]. Different studies 
show the presence of elevated ET-1 levels in breast cancer [13] [22]. Already in 2003, Wülfing et al. [23] published a study, which described the connection between ET-1 and its receptors (endothelin A receptor (ETAR) and endothelin B receptor (ETBR)). Furthermore, a possible therapeutic blockage of the endothelin receptors was discussed [24]. In 2008, a combination therapy was proposed, which would block the estrogen receptors (Tamoxifen) as well as the endothelin receptors (Bosentan) [25]; existing levels of ET-1 in the respective patients were not determined.

However, in the present study, we show that, at least in our breast cancer, collective, endothelin receptors are infrequently, and weakly expressed in invasive ductal carcinoma compared to the surrounding normal breast tissue, which suggests that an ET-blockade alone is an insufficient treatment option. Therefore, we decided to analyze the signaling pathway which is involved in the double treatment of a breast cancer cell lines, MCF-7, and MX1, with ET-1 and Tam, and its resulting gene expression, such as IL-6 and Wnt11. Furthermore, we present a novel target gene, Vimentin 3, associated with metastatic spread.

\section{Materials and Methods}

\section{Cell Culture}

MCF-7 cells were cultured as previously described [26]. MCF-7 cells were cultured in Dulbecco's Modified Eagle Medium (GIBCO) supplemented with $10 \%$ FCS (PAN Laboratories) and $1 \%$ Penicillin/Streptomycin (GIBCO) at $37^{\circ} \mathrm{C}$ and $5 \% \mathrm{CO}_{2}$. MX-1 cells were cultured in RPMI medium under the same conditions as previously described.

\section{Cell Treatments}

Cells were treated with endothelin-1 (50 nM), ß-estradiol (2 ng/ml) Tamoxifen $(10-6 \mathrm{~mol} / \mathrm{L})$. Before treatment, the cells were serum starved for $24 \mathrm{~h}$. The endothelin A and B receptor blockage was performed as previously described [26].

\section{In-Situ Detection of ET and ERß by Duolink Kit}

This detection kit (Sigma Aldrich), previously used by us [27], was employed with the following modifications. For fixation, a methanol:acetone $(1: 1, \mathrm{v} / \mathrm{v}) \mathrm{di}-$ lution was used. After removal of DMEM, slides were washed in PBS, air dried, and the cells fixed using ice-cold methanol:acetone (1:1, v/v) for $90 \mathrm{~s}$. After the fixation procedure, the Duolink kit was used according to the manual. The cells were incubated with a blocking solution in a pre-heated humidity chamber at $37^{\circ} \mathrm{C}$ for $30 \mathrm{~min}$, followed by primary antibody incubation for $2 \mathrm{~h}$ at room temperature. Antibodies used for detection were for ET-1 a mouse monoclonal antibody (Santa Cruz, sc-390243; 1:500), and for ERß a goat polclonal antibody (Santa Cruz, sc-21625; 1:500) for $1 \mathrm{hr}$ at RT. Incubation with the PLA probes for $1.5 \mathrm{~h}$ at $37^{\circ} \mathrm{C}$ followed, and the detection protocol was executed according to the recommended time points. After completing the final step, slides were mounted in Invitrogen fluorescence mounting medium with DAPI (Invitrogen) for nuc- 
lear staining. The Leica Aristoplan microscope with Discus software was used for visualization.

\section{Human Breast Tissue}

From a database of patients with breast cancer operated in the Department of Gynecology, University Hospital of Koeln, Germany, and analyzed in the Department of Pathology, University Hospital of Koeln, Germany, biopsies and mastectomy specimens with invasive ductal adenocarcinoma were selected. We studied 36 cases of ER $\alpha$ positive (all G2; Tam therapy; and consecutive mastectomies in 15 cases). In 8 cases the biopsies from subsequent metastases were also studied. In addition, 15 cases of ER $\alpha / \mathrm{PR}$ negative breast cancer biopsies (G3) which received a subsequent mastectomy were included All cases had been subjected to guideline-based routine histologic and immunohistologic analyses, and were now re-evaluated by a senior staff pathologist (J.W.U.F.), with regard to the quality and the quantity of the tumor tissue, in particular the biopsies from metastases.

\section{Tissue Microarray}

To assess the validity of the antibodies used (ET-1, vimentin full length, Vimentin 3), a tissue array made with $1.2 \mathrm{~mm}$ sized punch biopsies from selected breast carcinoma cases with different receptor status (ER $\alpha$, PR, Her-2/neu) was used.

\section{Histology and Immunohistology}

Sections and tissue blocks from mastectomy resection specimens and respective biopsies of metastases were used, being stored in the archives of the Department of Pathology, University Hospital of Cologne, Germany. These had been routinely processed by fixation overnight in $4 \%$ buffered formalin, subsequently embedded in paraffin, and sectioned $3 \mathrm{~mm}$ thick. All sections were stained with hematoxylin-eosin, and had been routinely analyzed by immunohistology, using antibodies against ER $\alpha$ (clone Sp1; 1:50; Ventana), against progesterone receptor (clone 16; read to use solution; Ventana) or against Herceptin receptor 2 (clone 4B5; ready to use solution; Ventana) as required by the German guidelines for the diagnosis, therapy and follow-up care of breast cancer. Sections were pretreated with EDTA (Leica Retrieval Solution 2) according to the manufacturer's instructions. The staining was performed using a BOND MAX stainer (Leica, Göttingen) and for detection a polymer with DAB as chromogen as applied. Hemalaun served as counterstain. Grading of staining intensity was performed in analogy to the ER/PR score by Remmele and Stegner.

The Vim3 antibody was commercially designed (EZbiolab, Inc.) using the unique C-terminal ending of Vim3 as target (for detailed information please see patent by University of Cologne, Brandenstein/Fries, patent number EP 13160876.2-1405). This antibody has been pre-evaluated; staining procedure was followed as previously outlined [28].

For immunohistology with the endothelin receptor antibodies, sections were pretreated with either EDTA ( $\mathrm{pH} 9.0)$ or citrate buffer $\left(\mathrm{pH} \mathrm{6.0)}\right.$ at $95^{\circ} \mathrm{C}$ for 25 
min followed by a block of endogenous peroxidase with $0.3 \% \mathrm{H}_{2} \mathrm{O}_{2}$ in TBS buffer. The Endothelin A receptor antibody (Life Span, Biosciences, Inc. Seattle), and the Endothelin B receptor antibody (Acris Antibodies, Herford) were pre-diluted with Zymed diluent (AR 1:75; BR 1:50) and incubated overnight at $4^{\circ} \mathrm{C}$.

Since human renal tissue was used, procedures were followed as outlined in accordance with ethical standards formulated in the Helsinki Declaration 1975 (and revised in 1983), or the Declaration of Istanbul (for control transplant biopsies), respectively, with pre-approval by the Ethics Committee at the University Hospital, Cologne (reference number: 09-232). All specimens were analyzed in Pathology in a blinded fashion. Informed consent forms from each patient had been obtained via the Department of Gynecology, University Hospital of Koeln, Koeln, Germany.

\section{Immunoprecipitation}

For immunoprecipitation, either the ET-1, ER $\alpha$ or $\operatorname{ER} \beta$ agarose conjugated antibody (Santa Cruz) was used. The assay was performed according to the Santa Cruz protocol with a $500 \mu \mathrm{g}$ total cellular protein. The final washing step was done $3 \times$ with PBS and the samples were diluted in $15 \mu \mathrm{l} 2 \times$ electrophoresis sample buffer. After a boiling step of $5 \mathrm{~min}$, the samples were centrifuged and used for Western blot analysis.

\section{Non-Radioactive Electrophoretic Mobility Shift assay (EMSA)}

Nuclear extracts were isolated from endothelin treated and untreated cells according to the manufacturer's protocol (Nuclear extraction kit, Active motif). Protein content was assayed with the Bradford protein assay (Bio-Rad) with BSA as standard.

EMSA probes used:

Target DNA

ERE of ER $\alpha$

ERE of ER $\alpha$ mut

Cold ER forw/rev

ER mut cold

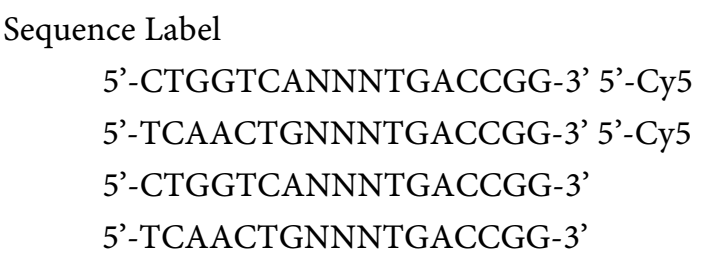

Nuclear Extract and Cytoplasmic Isolation

Nuclear and cytoplasmic extracts were isolated from treated cells and controls according to the manufacturer's protocol (nuclear extraction kit, Active motif) and as previously described [26].

\section{RNA isolation}

RNA was isolated with the RNeasy from Qiagen according to the manufacturer's protocol. RNA was quantified using the NanoDrop technology.

\section{RT-PCR and PCR}

The cDNA was obtained from 500 ng RNA using random primers and SuperScript III reverse transcriptase according to the manufacturer's protocol (Invitrogen). In order to be in the semi-quantitative range, the amount of cDNA was determined before by titration and the number of PCR cycles was standardized. The PCR reactions were performed in a final volume of $25 \mu$. For PCR reaction, 
$1 \mu \mathrm{l}$ of the RT-PCR product was always used. The PCR reactions were accomplished using of 40 cycles, each consisting of $30 \mathrm{sec}$ at $94^{\circ} \mathrm{C}, 1 \mathrm{~min}$ at the corresponding annealing temperature, and $1 \mathrm{~min}$ at $72^{\circ} \mathrm{C}$ with a final extension $10 \mathrm{~min}$ at $72^{\circ} \mathrm{C}$.

Primers used:

$\beta$-actin Forw 5'-TTGGCAATGAGCGGTTCCGCTG-3'

Rev 5'-GACAGCACTGTGTTGGCGTA-3'58

Vim3 Forw 5'-GAGAACTTTGCCGTTGAAGC-3'

Rev 5'-GAAATAAAATGCTTACCCCTCAG-3'58

IL-6 Forw 5'-GCTATGAACTCCTTCTCCACAAGCG-3'

Rev 5'-TGAAGAGGTGAGTGGCTGTC-3'58

Wnt-11 Forw 5'-CGTGTGCTATGGCATCAAGT-3'

Rev 5'-GCTCAATGGAGGAGCAGTTC-3'58

\section{Statistics}

The densitometric analysis of Western blot bands was performed with the ImageJ program as previously described [26] [27]. To determine the net signal of each band, the corresponding calculated value obtained from the loading control was regarded as 1 and the proportional value of each protein signal was calculated. For each cell line four qRT-PCRs were run, each containing a duplicate for each primer set. A paired t-test with a one-way ANOVA was performed using the Graph5 prism program. All data represent the mean of three independent experiments. GraphPrism 5 (GraphPad Software, La Jolla, Calif., USA) was used to calculate statistical significances with the Student's unpaired t-test $\left({ }^{*} \mathrm{p}<0.05\right.$, $\left.{ }^{* *} \mathrm{p}<0.01,{ }^{* * *} \mathrm{p}<0.001\right)$

\section{Western blot analysis}

Western blot analysis was performed as described in [26] [27]. For the analysis of the $\operatorname{ER} \alpha, \mathrm{ER} \beta, \mathrm{ET}-1$ and $\beta$-actin antibodies from Santa Cruz were employed and tested for specificity with Santa Cruz designed peptides.

\section{Results}

\subsection{Endothelin Receptor Expression Is Reduced in Invasive Adenocarcinoma of the Breast}

34 tissue samples of mastectomies due to invasive ductal adenocarcinoma (G2, $\mathrm{ER} \alpha$ positive) were analyzed by immunohistology for either the expression of Endothelin A or B receptor using a 3 grade scoring system (1+ weak, 2+ moderate, $3+$ strong) (data not shown). Corresponding, adjacently located normal breast tissue served as control. Healthy breast tissue shows in all cases membranous staining for endothelin receptors: ETAR expression was strong in 33\%, moderate in $33 \%$ and weak in $22 \%$. ETBR expression was found in $22 \%$ each, moderate and weak; no strong expression was observed. In contrast, in invasive ductal carcinoma, receptor positivity was rarely detectable: ETAR was observed moderately strong in 3 cases (9\%), and weakly detectable in 4 cases (12\%). The antibody for ETBR showed a strong staining in 6 cases (17.6\%), a moderate one 
in 3 cases (9\%), and a weak one in 2 cases (5.8\%). A correlation between ETAR and ETBR staining was not observed.

\subsection{Stimulation of MCF-7 Breast Cancer Cells with a Combination of Tam and ET-1 Downregulates ER $\alpha$ and Upregulates ET-1 and ERß}

Western blot analysis of MCF-7 cells with different mediators showed a distinctive change in the expression levels of ET-1 and the estrogen receptors (Figure 1(a)). According to the densitometric evaluation in Figure 1(b) (left diagram), ER $\alpha$ was detected in relatively high levels in non-stimulated MCF-7 cells (compared to ERß levels), and showed no statistically significant changed after stimulation with B-est, ET-1, combined B-est-ET-1 treatment. In contrast, highly significant downregulation occurred when the cells were treated with Tam alone or even in combination $B$-est, showing that $B$-est has no rescue function. However, a Tam treatment followed by ET-1 caused a highly significant upregulation even surpassing that of control levels. Thus, ET-1 reinstalls the accessibility of breast cancer cells for an $\mathrm{ER} \alpha$ mediated response.

ERß levels were low under control conditions and did not significantly change after treatment with $ß$-est, ET-1, or Tam, nor after the combined treatments with $B$-est and ET-1 (Figure 1(b), middle diagram). There was a slight increase in receptor detectability after $B$-est combined with Tam treatment. However, the combination of Tam with ET-1 resulted in a highly significant upregulation of the ERß receptor. The production of ET- 1 seems of an autocrine nature: as the densitometric result in Figure 1(b) (right diagram) demonstrates, ET-1 is highly upregulated after a combined Tam - ET-1 pretreatment, while these mediators by themselves or in combination with others do not exceed levels beyond those in control cells.

\subsection{Immunoprecipation of Nuclear Extracts with Either ET-1, ER $\alpha$ or ERß Agarose Conjugated Antibodies Reveals Different Complex Partners after Stimulation with ET-1 Alone or in Combination with Tam}

In Figure 2, three sets of Western blots are depicted after stimulation of MCF-cells with either ET-1, the combination of ET-1 and Tam versus nonstimulated control cells. Each blot shows results of an individual immunoprecipitation: in A with an anit-ER $\alpha$ agarose conjugated antibody; in B with an anti-ET-1 agarose conjugated antibodies, and in $\mathrm{C}$ with an anti-ERß agarose conjugated antibodies. While in control cells and after ET-1 stimulation in all three Western blots both ERs and ET-1 could be detected in the nucleus, after the combined ET-1 plus Tam pretreatment no ER $\alpha$ was found, while ERß was still present. Thus, a complex formation change transmigrating into the nucleus can be observed with loss of ER $\alpha$ once Tam and ET-1 are simultaneously stimulating MCF-7 cells. 


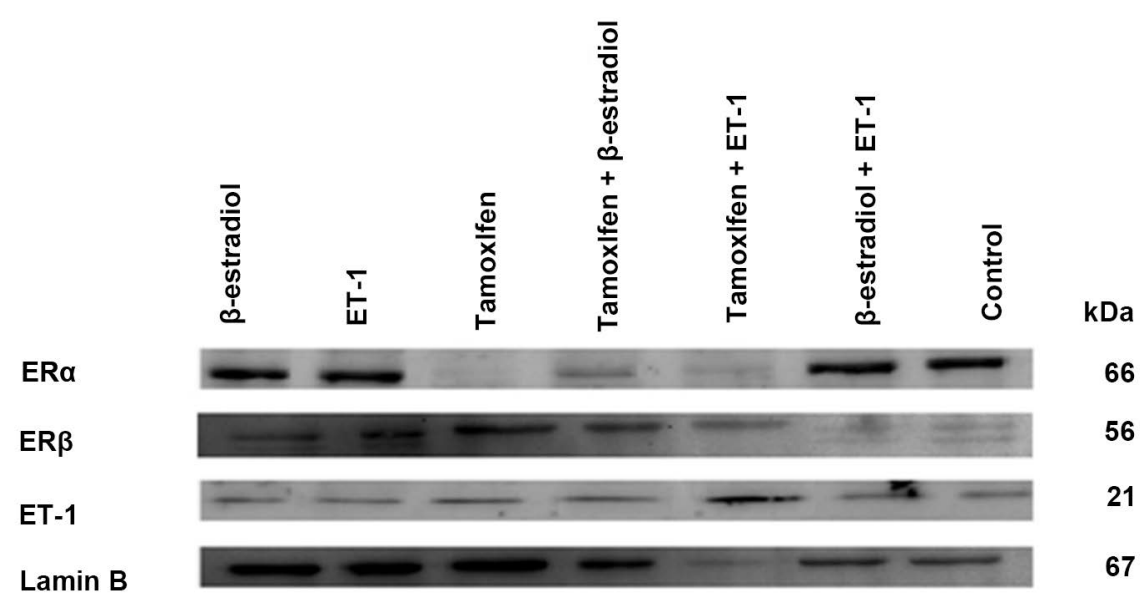

(a)

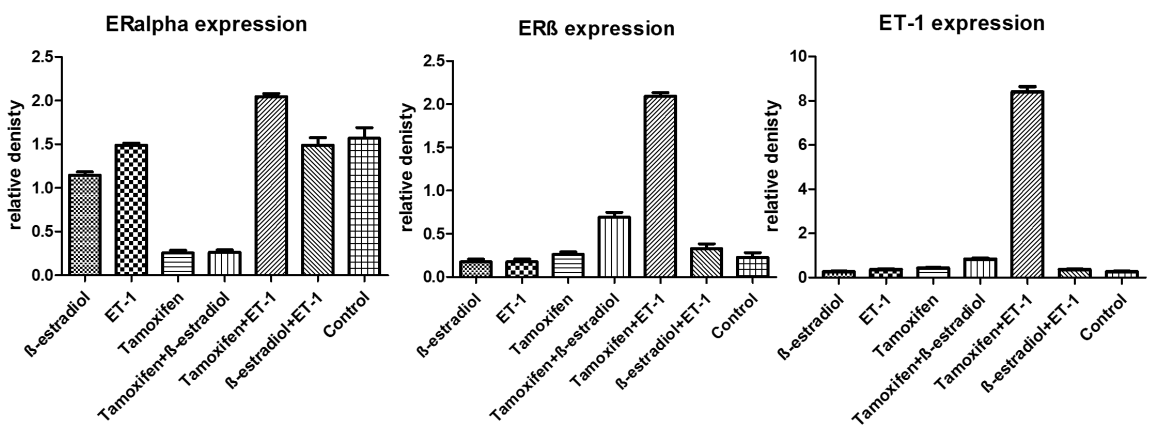

(b)

Figure 1. Western blot analysis of nuclear extracts of stimulated MCF-7 cells. (a) After Tam treatment of MCF-7 cells a clear decrease of the ER $\alpha$ in the nuclear fraction was detectable whereas ER $\beta$ increased, as well as ET-1. Lamin B was used as loading control and all signals for densitometry calculation used as $100 \%$. (b) Densitometric evaluation of A. High statistical significance is present for ET-1, and ERß expression $(\mathrm{p}<0.01)$ but not for ER $\alpha$ expression.

(a) Immuno - precipitation with ERa

ER $\alpha$

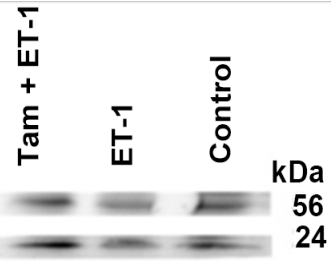

(b) Immuno - precipitation with ET-1

(c) Immuno - precipitation with ETß

ET-1

Figure 2. Immunoprecipitation with either ER $\alpha$ (a) or ET-1 antibody (b). Using either ET-1 (Figure 2(a)), ER $\alpha$ (Figure 2(b)) or ER $\beta$ (Figure 2(c)) agarose conjugated antibodies an immunoprecipitation demonstrates different complex partners after stimulation with ET-1 vs. Et-1 + Tam vs. nonstimulated control cells. 


\subsection{ERß and ET-1 Are Translocated into the Nucleus}

To demonstrate the concept of a complex transmigration into the nucleus containing ET-1 plus ERß, an immunofluorescence analysis was performed. In Figure 3(a) ERß can be demonstrated in the nucleus of MCF-7 cells by a directly fluorescein-labeled antibody, while ET-1 is visible using a directly rhodamine-labeled antibody at the same cell culture experiment. To show that these two proteins are present in a complex, a Duolink detection kit is used, which releases a fluorescent signal, if both proteins are within less than $40 \mathrm{~nm}$ distance from each other, as one might require forming an actual complex. In untreated cells, the signal is found in a perinuclear location, while it transmigrates after stimulation into the nucleus itself (Figure 3(b)).

\subsection{Electrophoretic Mobility Shift Assay with a Specific ER $\alpha$ Probe Excludes Tam}

To detect ER $\alpha$ proteins containing a DNA binding sequence, an electrophoretic mobility shift assay (EMSA) was performed, which utilizes designed and labeled oligonucleotides of the consensus ERE sequence of ER $\alpha$. Figure 4 shows the result of the EMSA where bands are present in the samples stimulated with B-est,
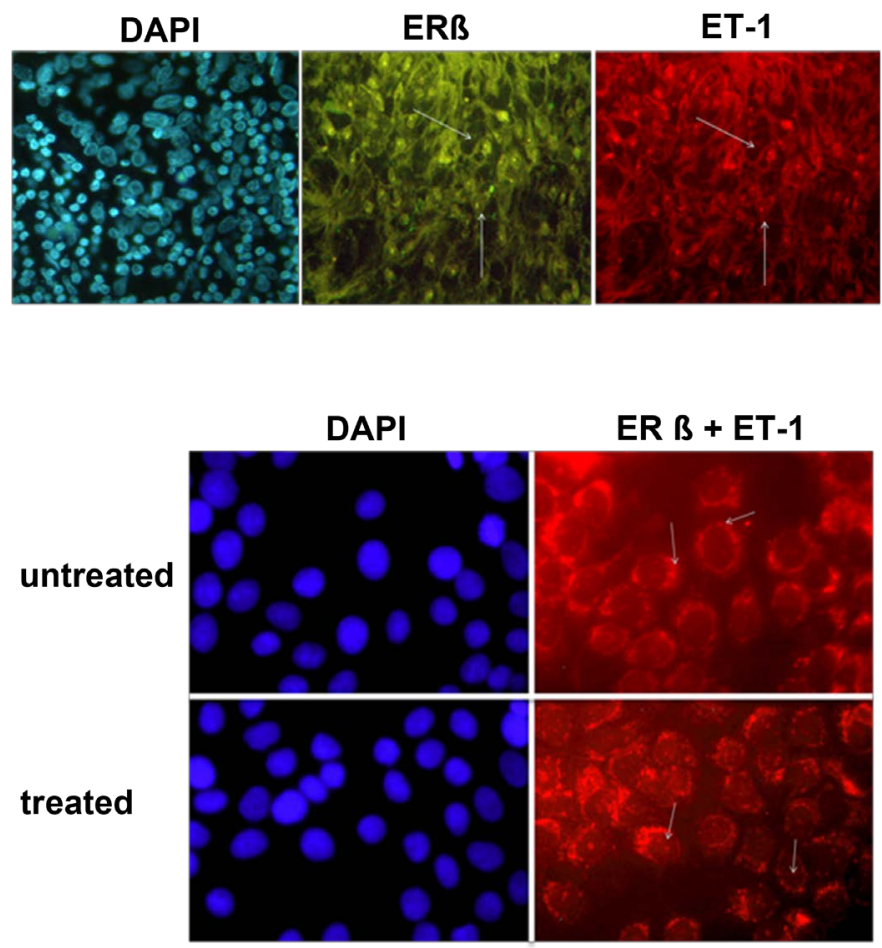

Figure 3. Nuclear expression of ERß after ET-1 pretreatment. By Immunofluorescence (Figure 4(a)), ERß and ET-1 can be demonstrated in then nucleus of MCF-7 cells after ET-1 stimulation; In Figure 4(b), the PLA assay shows that in untreated cells a signal formed by a complex between ET-1 and ERß in a perinuclear location. After ET-1 treatment, this complex has transmigrated into the nuclear compartment. DAPI servers as nuclear detection stain. 


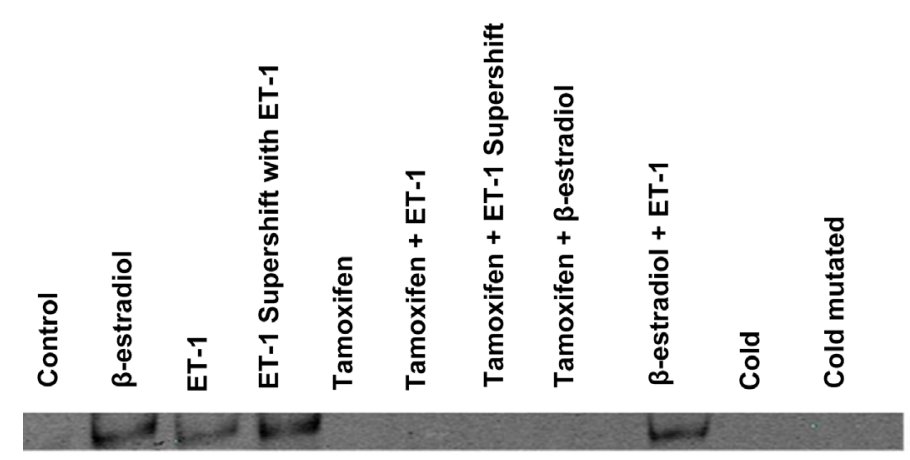

Figure 4. Non-radioactive EMSA with ET-1 supershift analysis. $5 \mu \mathrm{g}$ nuclear protein extracts of stimulated MCF-7 cells were incubated for the supershift with $3 \mu \mathrm{L}$ of ET-1 antibody and then with palindromic, Cy5 labeled oligonucleotides representing the consensus ERE sequence of ERa. The 6\% non-denaturing polyacrylamide gel was run for 180 $\min$ at $120 \mathrm{~V}$. Complex formation is observed in the samples $\beta$ est, ET-1 and $\beta$-est + ET-1. A supershift due to an increased complex size with ET-1 antibody can be seen for MCF-7 cells stimulated with ET-1.

ET-1, ET-1+ supershift with ET-1 and B-est+ET-1. The band in the lane of ET-1+Supershift with ET-1 is located higher on the gel indicating a shift in mobility due to the binding of the ET- 1 antibody the ERE-ER $\alpha$ complex.

\subsection{IL-6 and Wnt11 Are Target Genes of ET-1 Stimulation in MX-1 and MCF-7 Cells}

When both cell lines, MX-1 (Figure 5(a), and Figure 5(b)) and MCF-7 cells (Figure 5(c), and Figure 5(d)), are stimulated with Tam or one if its respective combinational settings (Tam $+\beta$-est and Tam + ET-1) the gene expression of the described target genes IL- 6 and Wnt11 is significantly altered. The differences between the mean values observed among the stimulation settings were proven to be significant with a paired t-test. In MCF-7 as well as in MX-1 the Vim3 gene expression increased steadily with Tam, Tam $+\beta$-est and Tam + ET- 1 stimulations until a fold change of around $700 \mathrm{RFU}$ were reached. The expression level of IL-6 shows a similar Tam + ET-1-dependent increase with fold changes around $120 \mathrm{RFU}$. The Wnt-11 gene expression shows increases up to $100 \mathrm{RFU}$ upon Tam + ET-1 stimulation. These results indicate that due to the stimulation with Tam together with ET-1 a pro-invasive gene response is triggered in breast cancer cell lines as the chosen genes have been correlated with metastasis and tumor progression. For both genes, pretreatment with Tam in combination with B-estradiol but particularly with ET-1 resulted in statistically significant target gene level upregulation in comparison to stimulation with either mediator alone $\left({ }^{*} \mathrm{p}<0.05\right)$.

\subsection{Vim3 Is a Novel Target Gene for Pretreatment with Tam Combined with Either ß-Estradiol or ET-1}

Using the same setting as in Figure 5, we studied the expression of Vim3 by RT-PCR in stimulated MCF.7 cells. We observed a highly significant 
II-6 expression

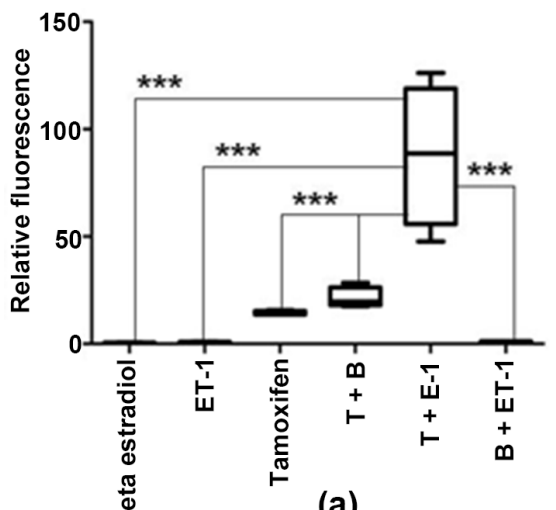

(a)

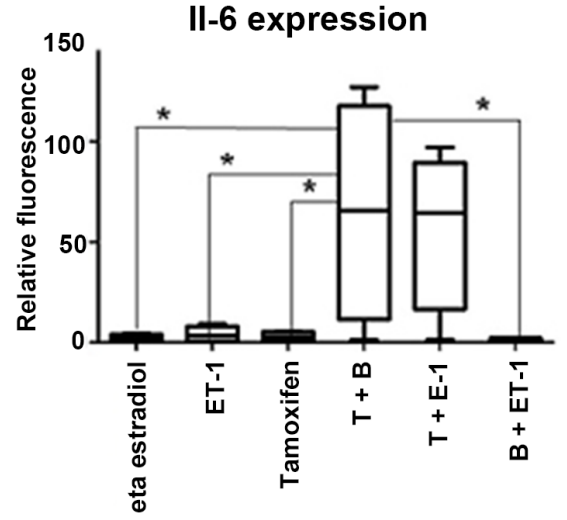

(c)
Wnt-11 expression

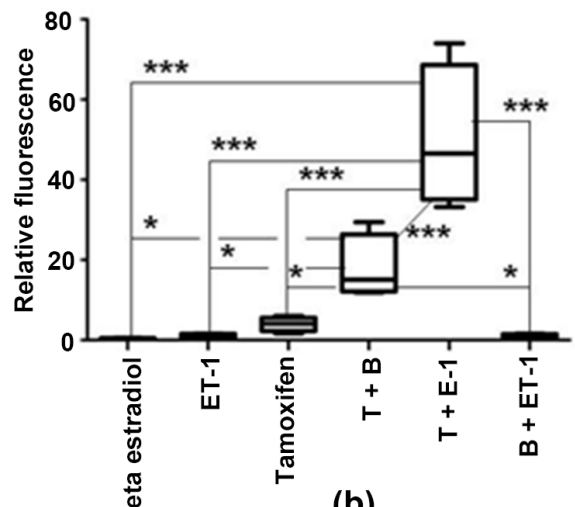

(b)

Wnt-11 expression

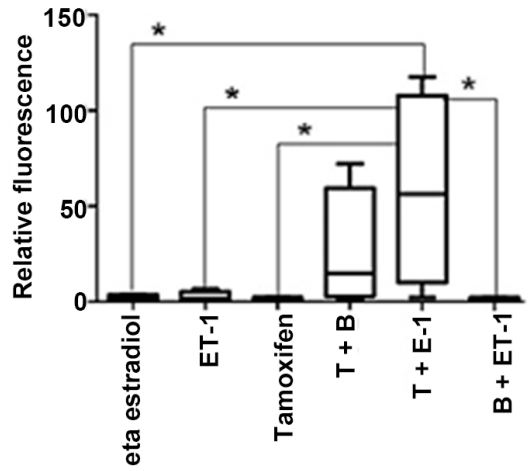

(d)

Figure 5. IL-6 and Wnt-11 gene expression levels in MX-1 (a), (b), and in MCF-7 c (c), (d) cells after stimulation by qRT-PCR anaylsis. (a) presents the obtained graph for the paired t-test of IL-6 fold changes. (b) represents the expression levels of Wnt-11 after stimulation with different settings. Both graphs show that the highest expression level upon T + ET-1 stimulation of MX-1 cells shows a significant increase when compared to the other stimulation settings. Data shown is derived from quadruplicates from one independent experiments. ${ }^{\star} \mathrm{P}<0.05$ and ${ }^{* * *} \mathrm{P}<0.001$. The respective results for MCF-7 cells in C (IL-6), and D (Wnt11) after ET-1 stimulation. ${ }^{\star} \mathrm{p}<0.05$

upregulation of gene expression $\left({ }^{* *} \mathrm{p}<0.01\right)$ when the pretreatment combination of Tam and either $\beta$-est or particularly ET-1 was used (Figure 6(b)).

When MX-1 cells were analysed for Vim3, (Figure 6(a)), the fold changes of Vim3 expression in the stimulation settings containing Tam show the same drastic increase as observed with stimulated MCF-7 cells. The results are also identical for the stimulation settings where no Tam is involved and the gene expression level does not significantly change or increase.

\subsection{Triple-Negative MX-1 Expresses ER $\beta$}

As the PCR showed unexpected results of ERß transcripts in MX-1, protein levels were investigated by Western blot. Figure 6(a) shows the results of $20 \mu \mathrm{g}$ nuclear extract of stimulated MX-1 probed with ER $\beta$, ET-1 and Lamin B 
Vim3 expression

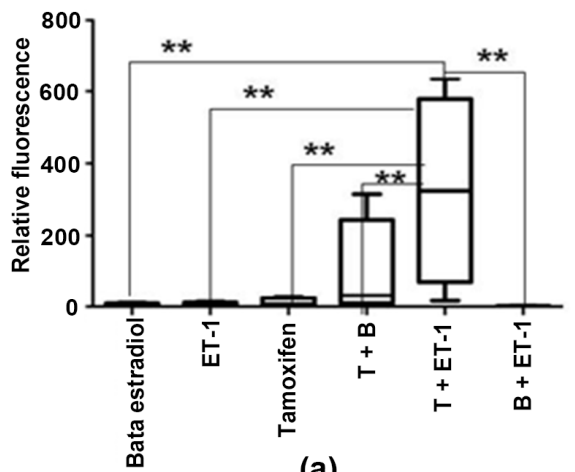

(a)
Vim3 expression

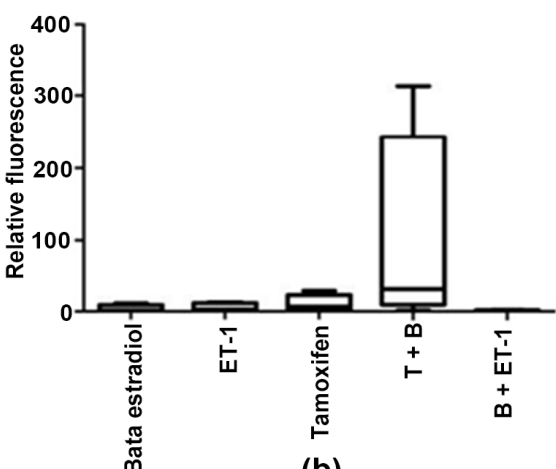

(b)

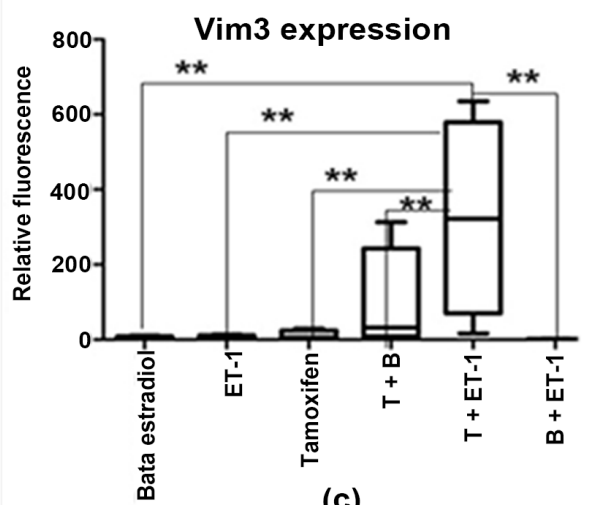

(c)

Figure 6. Vim3 expression analysis of treated MX-1 (a), (b), and MCF-7 (CC) cells by qRT-PCR analysis. In MX-1 cells, (a) shows the complete stimulation set-up where the paired t-tests have a significant difference when comparing stimulations. (b) shows the same without the T + ET-1 values to get details on the other stimulation settings which all represent significant different means after paired t-test. In both diagrams the increase in Vim3 expression up to ca 700 RFU upon a combinational stimulation with Tam is decisive. Data shown is derived from quadruplicates from an independent experiment. ${ }^{*} \mathrm{P}<$ $0.05,{ }^{*} \mathrm{P}<0.01$ and ${ }^{* *} \mathrm{P}<0.001$. Results from MCF-7 cells for Vim3 in (c) showing a clear increase in mRNA Vim3 expression after combined pretreatment with tamoxifen and $ß$-estradiol/ET-1; ${ }^{* *} \mathrm{p}<0.01$.

antibody (as loading control). We found $\operatorname{ER} \beta$ after all different stimulations, with slightly varying intensity.

\subsection{Tam Upregulates Vim3}

Furthermore, we studied the effect of Tam with regard to its translational capacity for Vim3 after a combined Tam plus ET-1 pretreatment versus ET-1 alone. As the analysis of the Western blot (Figure 7(a)) depicts by densitometry (Figure 7(b)), adding Tam as additional mediator to ET-1 results in highly statistically significant induced formation of Vim3 $\left({ }^{* * *} \mathrm{p}<0.001\right)$.

\subsection{Vim3 Expression in Invasive Ductal Breast Carcinoma, and Its Metastases}

From our pre-evalution of breast cancer specimen via tissue-microarray we knew, that ET-1 and Vim3 staining could be detected in tumor cells, while 


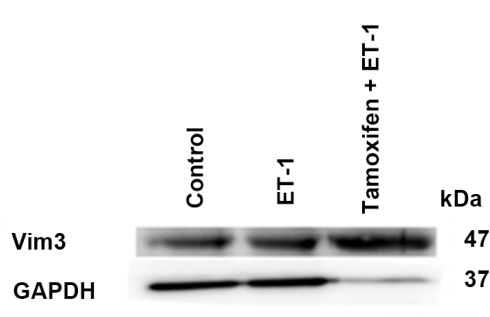

(a)

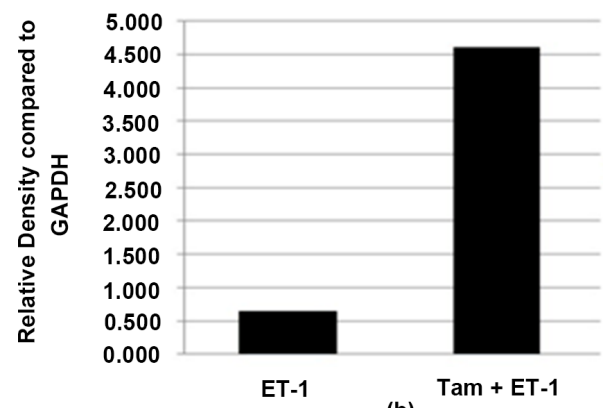

(b)

Figure 7. Comparison of Vim3 expression after ET-1 vs. combined ET-1 plus Tamoxifen pretreatment. WB with $20 \mu \mathrm{g}$ non-precipitated total cell extract of stimulated MCF-7. (a) shows the protein analysis on the WB membrane where the intense band of Vim3 $(47 \mathrm{kDa})$ is striking as compared to the very faint band of GAPDH in the same sample. (b) shows the corresponding densitometric analysis of the present bands with ImageJ, where the background and the control had been subtracted.

vimentin full length was only positive in the interstitial tissue (data not shown).

To analyze the expression of the newly described target gene Vim3 in more detail, we investigated its expression in 28 biopsies and their respective resection specimens of breast cancer cases. All biopsies showed grade 2 invasive carcinoma positive for ER $\alpha$ expression (Table 1). In each biopsy, Vim3 was detected, either in nuclear (20/25; strong expression: $3+$ ) and/or diffuse cytoplasmic $(25 / 25)$ localization. After Tam treatment, seventeen respective resection specimens were still diffusely positive for Vim3, now mainly in a cytoplasmic localisation (12/17), with nuclear localization additionally found in 5 specimens (5/17). In 4 cases, lymph node but no other metastases were reported (4/28). In contrast, 7 cases developed organ metastases (7/28), of which 3 had additional lymph node metastases.

\subsection{Vim 3, Co-Expressed with ERß in Invasive Ductal Carcinoma Specimens, Is Associated with Metastatic Spread}

We studied the expression of Vim3 and ERß in resection specimens and their metastases Table 2). In a set of 8 cases positive for ER $\alpha$ after tam pretreatment, we found again a diffuse cytoplasmic expression of Vim3. In addition, in 10/12 metastases (pleura $2 \times$, skin $2 \times$, bone $3 \times$, uterus $1 \times$, liver $1 \times$, soft tissue $1 \times$ ) Vim 3 was also expressed (cytoplasm: 12/12; additional nuclear expression 5/12). In 7 of the 12 metastases, a 3+ nuclear expression for ERß was found, which was always accompanied by Vim3 expression.

\subsection{ERß Is Expressed in ER $\alpha$ Negative Breast Cancer}

In addition we analysed $15 \mathrm{ER} \alpha$ negative tumor biopsies of invasive ductal carcinoma (G3) for the presence of ERß (Table 3). All cases showed a cytoplasmic positivity for ERß (15/15); 4 cases displayed a strong nuclear expression. Those cases were simultaneously positive for Vim 3 in tumor nuclei. 
Table 1. Analysis if Vim3 expression in ERa biopsy and matching mastectomy specimens. Almost all biopsies show a nuclear positivity for Vim3 (19/21), which is changed to a cytoplasmic staining in mastectomies after Tam (13/17). Yes/No. biopsy or mastectomy performed/year of performance; LNmet lymph node metasatses; $\mathrm{n}+$ nuclear positivity; $\mathrm{c}$ + cytoplasmic positivity; $M$ distant metastastic stage; SK sinus carcinosis; empty box no clinical data available.

\begin{tabular}{|c|c|c|c|c|c|c|}
\hline$\#$ & Biopsy & Vim3 & Mastectomy & Vim3 & Lnmet & $\mathrm{M}$ \\
\hline 1 & yes/12 & $\mathrm{n}+$ & yes/12 & $\mathrm{n}+$ & 0 & 0 \\
\hline 2 & yes/12 & $\mathrm{n}+$ & yes $/ 13$ & $c+$ & 0 & 0 \\
\hline 3 & yes/08 & $\mathrm{n}+$ & yes $/ 08$ & $c+$ & 0 & 0 \\
\hline 4 & yes/12 & $\mathrm{n}+$ & yes $/ 12$ & $c+$ & 0 & 0 \\
\hline 5 & yes/03 & $\mathrm{n}+$ & yes/09 & $c+$ & 0 & 0 \\
\hline 6 & yes/12 & $\mathrm{n}+$ & & & 0 & 0 \\
\hline 7 & yes/12 & $\mathrm{n}+$ & & & 0 & 0 \\
\hline 8 & yes/ & $\mathrm{n}+$ & yes/15 & $c+$ & 0 & 0 \\
\hline 9 & yes/03 & $\mathrm{n}+$ & & & 0 & 0 \\
\hline 10 & yes/ & $\mathrm{n}+$ & yes $/ 12$ & $c+$ & 0 & 0 \\
\hline 11 & yes/12 & $\mathrm{n}+$ & yes/12 & $c+$ & 0 & 0 \\
\hline 12 & yes/12 & $\mathrm{n}+$ & & & 0 & 0 \\
\hline 13 & yes/12 & $\mathrm{n}+$ & & & 0 & 0 \\
\hline 14 & yes/03 & $\mathrm{n}+$ & & & 0 & 0 \\
\hline 15 & yes/14 & $\mathrm{n}+$ & & & 0 & 0 \\
\hline 16 & yes/ & $\mathrm{n}+$ & yes/15 & $\mathrm{n}+$ & 0 & 0 \\
\hline 17 & yes/09 & $\mathrm{n}+$ & yes/09 & $c+$ & $0, \mathrm{SK}$ & 0 \\
\hline 18 & yes/14 & $\mathrm{n}+$ & yes/14 & $c+$ & pos & 0 \\
\hline 19 & yes/12 & $\mathrm{n}+$ & yes/13 & $\mathrm{n}+$ & pos & 0 \\
\hline 20 & yes/14 & $\mathrm{n}+$ & yes/14 & $c+$ & pos & 0 \\
\hline 21 & yes/14 & $\mathrm{n}+$ & & & pos & 0 \\
\hline 22 & yes/12 & $\mathrm{n}+$ & yes/14 & $\mathrm{n}+$ & & M1 \\
\hline 23 & yes/14 & $\mathrm{n}+$ & & & & M1 \\
\hline 24 & yes/ & $\mathrm{n}+$ & yes $/ 12$ & $\mathrm{n}+$ & & M1 \\
\hline 25 & yes/12 & $\mathrm{n}+$ & & & & M1 \\
\hline 26 & yes/14 & $\mathrm{n}+$ & yes/14 & $c+$ & pos & M1 \\
\hline 27 & yes/15 & $\mathrm{n}+$ & & & pos & M1 \\
\hline 28 & yes/ & $\mathrm{n}+$ & yes/14 & $c+$ & pos & M1 \\
\hline
\end{tabular}

\section{Discussion}

This paper analyzes in vitro and in human breast tissue the effect of a complex formation between ERß and ET-1 on upregulation of genes such as Vim 3 in association with Tam. This promotes a more aggressive behavior of invasive ductal carcinoma than in the absence of Tam, when ET-1 is forming a complex with $\mathrm{ER} \alpha$ (see diagram, Figure 9). 
Table 2. ER $\alpha$ positive mastectomy specimens after Tam with one (1. Met.) or two (2. Met.) distant metastases. Yes/No. mastectomy/year; $\mathrm{n}+$ nuclear positivity; $\mathrm{c}+$ cytoplasmic positivity.

\begin{tabular}{cccccccc}
\hline No. & ERa/PR/Her & Vim3 & Erß & 1.Met & Vim3 & 2.Met & Vim3 \\
\hline 1 & triple neg & c + & neg & pleura & $\mathrm{c}+$ & & \\
2 & $3+/ 3+/ 1+$ & $\mathrm{c}+$ & neg & LN & $\mathrm{c}+$ & & \\
3 & $3+/ 2+/ 1+$ & $\mathrm{c}+$ & & pleura & $\mathrm{c}+$ & & \\
4 & $3+/ 3+/ 0$ & $\mathrm{c}+$ & & skin & $\mathrm{n}+/ \mathrm{c}+$ & & \\
5 & $3+/ 0 / 0$ & $\mathrm{c}+$ & neg & skin & $\mathrm{n}+/ \mathrm{c}+$ & & \\
6 & $3+/ 3+/ 0$ & $\mathrm{c}+$ & & vertebra & $\mathrm{c}+$ & rip & $\mathrm{n}+/ \mathrm{c}+$ \\
7 & $3+/ 1+/ 0$ & $\mathrm{c}+$ & neg & skin & $\mathrm{c}+$ & liver & $\mathrm{n}+/ \mathrm{c}+$ \\
8 & $3+/ 0 / 2+$ & $\mathrm{c}+$ & neg & uterus & $\mathrm{c}+$ & skin & $\mathrm{n}+/ \mathrm{c}+$ \\
\hline
\end{tabular}

Table 3. ERß status and Vim3 expression of ERa negative mastectomy specimens.

\begin{tabular}{ccccccc}
\hline No. & ERa & Her2 & ERß $~$ & ERß $~$ & Vim 3 & bx/res \\
\hline 1 & neg & $2+$ & & pos & & bx \\
2 & neg & $3+$ & pos & & n; 3+ & bx \\
3 & neg & $2+$ & & pos & & res, G3 \\
4 & neg & neg & pos & & n; $3+$ & bx \\
5 & neg & $2+$ & & pos & & bx \\
6 & neg & $2+$ & & pos & & bx \\
7 & neg & $3+$ & & pos & neg & bx, DCIS \\
8 & neg & $2+$ & & pos & & bx \\
9 & neg & $2+$ & & pos & & bx \\
10 & neg & $2+$ & & pos & & bx/res \\
11 & neg & $2+$ & & pos & & bx \\
12 & neg & $2+$ & & pos & & bx \\
13 & neg & $2+$ & & pos & & bx \\
14 & neg & $3+$ & pos & & $\mathrm{n} ; 3+$ & $\mathrm{bx}$ \\
15 & neg & $3+$ & pos & & $\mathrm{n} ; 3+$ & $\mathrm{bx}$ \\
\hline
\end{tabular}

In the literature, an important role of ET-1 in the progression of breast cancer, and particularly for its invasive behavior [22] [23] is proposed, making it a potential target for anticancer therapy [24]. Knowing that ET-1 is able to use both of its receptor isoforms to exert its function in different cell lines, we started our study by analyzing a collective of 34 cases of mastectomy of ER $\alpha$ positive, invasive ductal carcinoma (G2) by immunohistology for ETA and ETB receptor expression. The presence of both receptors was detectable in agreement with the literature on normal breast tissue as well as on the surface of invasive ductal adenocarcinoma carcinoma. However, the expression of endothelin receptors at the tumor cell surface was lower and weaker than the respective control breast tissue, so that this therapeutic approach seems insufficient as exclusive therapeu- 
tic approach, while it may be still considered for an adjunct therapy. However, there is no obvious pathophysiologic explanation for the problems associated with a Tam therapy.

Thus, we undertook the present cell culture study and a separate immunohistologic evaluation of human breast cancer specimens. The rationale for the cell culture study was that the binding of ET-1 to the ER needs to be proven as well as finding target genes that are up- or down-regulated when the breast cancer cell line is stimulated with the different treatments. Particularly four aspects are addressed: 1) Difference in stimulation with or without Tam and the ER switch; 2) Translocation of ER transcription complexes; 3) Target gene expression relevant for metastatic potential; 4) Development of an invasive phenotype. We used two breast cancer cell lines: MCF-7 was chosen as it is an ER+ cancer cell line expressing ER $\alpha$, ER- $\beta$ and the GPER [29]. We investigated as different treatments $\beta$-est as the normal hormonal situation where the tumor proliferates in the hormone's presence; ET-1 to see whether it can trigger a specific gene response on its own, and Tam.

The MX-1 cell line was chosen for further analysis of the gene expression after Tam and ET-1 stimulation since the cell line is known from literature to be triple-negative [30], thus expressing no ER, progesterone or human epidermal growth factor-2 receptor (HER2+). Using this cell line, the absence of the needed receptor would trigger no comparable gene expression and confirm its obligate involvement in the triggering of specific gene response. However, we found a positivity of MX-1 cells for ERß by qRT-PCR (data not shown) as well as by Western blot (Figure 8). This result clearly shows possible problems arising through disregarding ERß, and the need for carefully analyzing commercially provided information used in experimental setting without further control. Furthermore, we recognized a negative effect of tamoxifen on the level of laminB expression (Figure 8). As it is known from the literature, tamoxifen causes premature senescence in human breast cancer [31], thereby decreasing lamin B levels due to receptor downregulation [32].

1) Difference in stimulation with or without Tam and the ER switch

While in nuclear extract blots of MCF-7 cells (Figure 1) after ET-1 and $\beta$-estradiol stimulation, ER $\alpha$ is clearly detectable by Western blot, the stimulation of Tam, Tam $+\beta$-est and Tam + ET- 1 shows a clearly decreased protein signal. In addition, in MX-1 cells, this increased presence of ET-1 can be detected in all Tam containing stimulations (Figure 8). This indicates that together with Tam, ET-1 is continuously taken up and/or produced by the breast cancer cells. To show the direct interaction between possible complex partners, we used immunoprecipitation with agarose beads containing ER $\alpha$. These showed that ET-1, ER $\alpha$, and ERß are able to form a transcription complex (Figure 2(a)). However, using an ERß antibody as the anchoring molecule, only ET-1 was detected when stimulating with TAM and ET-1 (Figure 2(c)).

In addition, by EMSA with a Cy5-labeled ER $\alpha$ probe, we could show (Figure 4) that ER $\alpha$ is not part of a complex containing Tam or Tam plus ET-1, further 


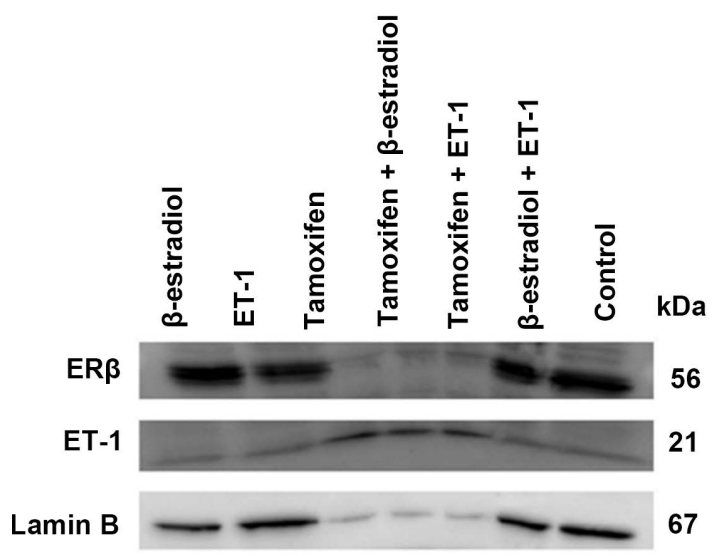

Figure 8. MX-1 cells produce ERß. Western blot of 20 $\mu \mathrm{g}$ of stimulated MX-1 cells nuclear protein extracts probed with ERß or ET-1 antibodies, quantified by densitometry using Image J. ET-1 is detectable in all settings. Lamin B was used as loading control.

supporting the concept of a switch in the signaling partner from ER $\alpha$ to ERß after Tam pretreatment.

\section{2) Translocation of ER transcription complexes}

In nuclear extracts from breast cancer cells, after treatment with either ET-1, ß-est, Tam or a combination of them, a significant upregulation of the ET-1 signal in the nuclear fraction after Tam treatment was detectable. The translocation of ET-1 into the nucleus is receptor dependent. Therefore we performed an immunoprecipitation and showed that the translocation is not ER $\alpha$ dependent. Next we have shown by immunofluorescence in Figure 3(a) that ERß and ET-1 are detectable in the nucleus of ET-1 stimulated MCF-7 cells. This indicated the functional importance of ERß after translocation, reflecting the observation in the literature that ERß positive tumors can have a poor outcome. Since the ERß receptor has a functional nuclear location sequence, and by that serving as a chaperone to ET-1, we performed a PLA assay, showing that the ET-1 and the ERß build a complex (Figure 3(b)).

\section{3) Gene target expression relevant for metastatic potential}

The autocrine regulatory role of ET- 1 in the growth of several tumor types [33] has been shown to be involved in the transcriptional level of progressing breast cancer. Therefore, in order to determine how ET-1 mediates its involvement in tumor invasiveness and angiogenesis, we analyzed proteins, being associated with a pro-invasive phenotype and progression of the tumor cells. We found in both cells lines, MX-1 and MCF-7 (Figure 5(a), Figure 5(a): MX-1; Figure 5(c), Figure 5(d): MCF-7), that levels of both proteins, IL-6 and Wnt11, are significantly increased following treatment with a tam/ET-1 combination. The importance of those proteins for potential breast cancer invasiveness has been recognized in several publications.

Interleukin 6, a cytokine that was originally identified as a regulator of in- 
flammatory and immune responses [34], has been observed in increased levels in metastasizing breast tumors and is involved in tumorigenesis. In vitro, IL-6 treatment promoted the invasiveness potential of MCF-7 cells in a dose-dependent manner [35].

Wnt-11 has been described as a marker for progression and metastases [36] [37]. It is a member of the canonical WNT gene family. As such, it encodes secreted signaling proteins. Its particular role in oncogenesis has been described in the increased motility of cancer cells [38]. Furthermore, Wnt11 may play a role in modifying tumor stroma: cancer-associated fibroblasts have been noticed to produce exosomes, which are taken up by breast cancer cells, and being subsequently loaded with Wnt11, and released [39]. The up-regulation of Vim3, IL-6, Wnt11 and the Wnt-signaling genes upon Tam + ET-1 stimulation confirm that the adjuvant treatment with Tam and co-existence of ET-1 may cause breast carcinoma to progress. This could explain the fact that $50 \%$ of patients experience a de novo resistance to Tam therapy [40].

The third protein, Vimentin 3, a splicing variant of vimentin [41], provides an increased mobility in cancer cells due to its missing 3 ' tail. The expression of vimentin in cancer types is directly linked to tumor growth, invasion and poor prognosis for the patient [42]. Further potential roles of this splicing variant type 3 of vimentin are presently under investigation, since its upregulation is oberserved in several different tumor types (patent pending). As Figure 5 depicts, levels of Vim 3 are equally increased as seen with IL- 6 and Wnt11 in Figure 4 by the tam - ET-1 complex in both cells lines, MX-1 and MCF-7 (Figure 6(a), Figure 6(b): MX-1; Figure 6(c): MCF-7). This indicated a special role for Vim3, which was further elucidated using human specimens.

The importance of ERß for transcriptional activation of our target genes is also highlighted by the qRT-PCR results of the MX-1 cells: being heralded as ERß negative, they should have no signals detecable, if ER $\alpha$ does not play a role after tam treatment instead the results are quite similar to the ones of the MCF-7 cells.

\section{4) Development of an invasive phenotype}

The final requirements for this new mechanism are changes associated with an invasive phenotype. The nuclear translocation of ER $\beta$, Tam and ET- 1 upon Tam-dependent stimulation explains the observed over-expression of Vim3, IL-6 and Wnt-11. The up-regulation of these markers for metastases due to the presence of this nuclear complex confirms the finding of Speirs and collegues [43] that patients with a SERM-resistant, pre-invasive mammary tumors show an altered expression of ER $\beta$. From the literature [44] it is also known that the $\mathrm{ER} \beta$ can antagonize ER $\alpha$-dependent transcription or even suppress the ER $\alpha$ mediated transcription completely [45]. Only when Tam is involved in the stimulation setting, $\operatorname{ER} \beta$ can be found in the nucleus. There, it then can antagonize the usually negative effect Tam has on tumor progression and growth. The increase in gene expression of our markers for metastases directly correlates with this 
special feature of $\mathrm{ER} \beta$ translocation into the nucleus.

While we had shown by qRT-PCR in Figure 6 that in both cell lines used Vim3 was statistically significantly upregulated after treatments using Tam plus ß-est or ET-1 simultaneously, it was important to confirm this effect at the level of translation. As the Western blot in Figure 8 depicts, Vim3 can be detected under control conditions, and being upregulated by ET-1 stimulation in MCF-7 cells. However, the greatest intensity is observed, when both stimulators, ET-1 and Tam are used simultaneously, resulting in a densitometric increase 9 times higher than with ET-1 alone. Since it is found that the Vim3 protein is exclusively synthesized inside the cells that had been stimulated with Tam + ET-1, it further supports our statement, that Tam + ET-1 may trigger a pro-invasive phenotype of breast cancer cells.

In nuclear extracts from breast cancer cells, after treatment with either ET-1, B-est, Tam or a combination of them, a significant upregulation of the ET-1 signal in the nuclear fraction after Tam treatment was detectable. The translocation of ET-1 into the nucleus is estrogen receptor dependent, therefore we performed an immunoprecipitation and showed that the translocation is not ER $\alpha$ dependent. From the literature it is known that ERß positive tumors have a poor outcome. Since the ERß receptor has a functional nuclear location sequence, we decided to perform a PLA assay, showing that the ET-1 and the ERß build a complex (Figure 3).

To summarize the concept based on our cell culture results, we propose a pathomechanism depicted in Figure 9. In the left side of Figure 9(a) in the presence of $B$-est, and ET-1, a signaling cascade is activated in which B-est and ET-1 is complexed with $\mathrm{ER} \alpha$, transmigrating into the nucleus, while ERß is not participating. No significant increase in IL-6 and Wnt11 is observed; the amount of detecable Vim3 is minimal. This is in contrast to the mechanism after the treatment with Tam (Figure 9(b)). ER complex formation leads here to a switch in the respective partner, in which now ERß and not ER $\alpha$ complexes with tamoxifen and ET-1. After nuclear transmigration, there is strong induction in target genes, involving IL-6, Wnt11, and Vim3, here described for the first time.

\section{5) Relevance of cell culture results for human breast cancer}

To demonstrate that the cell culture results have relevance for the treatment of breast cancer patients in daily practice, we studied biopsies and mastectomy specimens from invasive ductal carcinoma. For that purpose, the identification of patients who belong to the subgroup in Figure 9(b) is important and requires the analysis of target genes associated with ERß. Since the overexpression of Vim3 is possibly responsible for the higher metastatic potential of a tumor, and knowing that under Tam treatment some patients still developed metastases, we focused on this novel marker in our investigation. The cases of formalin-fixed and paraffin-embedded tissue samples archived at the Department of Pathology were derived from patients either ER $\alpha$ positive and receiving Tam treatment or $\mathrm{ER} \alpha$ negative. In the ER $\alpha$ positive group (Table 1), 26/28 biopsies showed a 


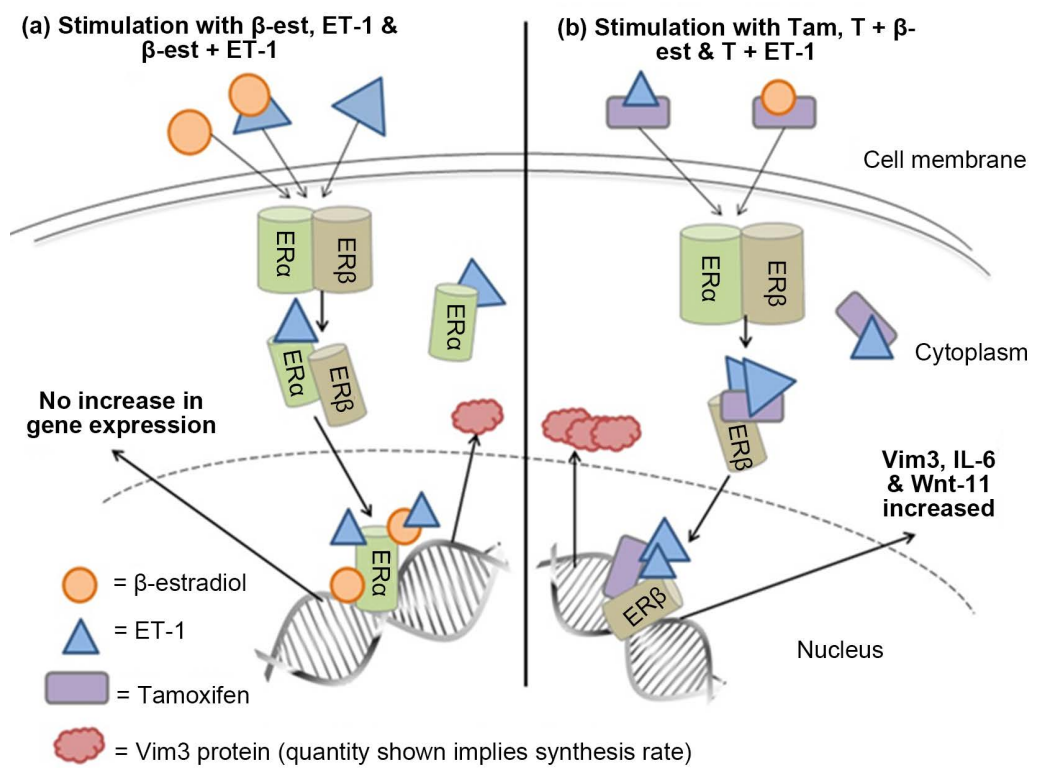

Figure 9. Schematic depiction of ER signaling switch and target gene expression after treatment without (a) or with (b) tamoxifen.

nuclear Vim 3 expression, which was shifted to the cytoplasm in most of the 17 matching mastectomy cases (12/17), whereas 5 cases still showed a nuclear staining pattern. Most importantly, $25 \%$ had lymph node metastases, and an additional M1 stage was found in 25\% after Tam treatment.

To further characterize the importance of a possible interaction between ERß and Vim3, we immunohistologically investigated the expression of these two protein in 8 mastectomy specimens being $\mathrm{ER} \alpha$ positive and their respective non-lymph node metastases (Table 2). Here, all mastectomy cases and their metastases showed a positivity for Vim3. In addition, in 7/12 metastases, a simultaneous ERß expression could be detected. This seems particularly relevant in the light of a report, that increased serum ET-1 levels can also be found in breast cancer patients with lymph node metastases, when compared to those patients having no lymph node involvement [24], while a breast tumor exposed to endothelins led to an invasive tumor phenotype in vitro [46]. To highlight the importance of ERß in the absence of $\mathrm{ER} \alpha$, we studied 15 cases of $\mathrm{ER} \alpha$ negative mastectomy specimens (Table 3). All tumors showed a strong cytoplasmic, in three an additionally nuclear ERß expression, while all cases had a positive nuclear staining for Vim3.

From these observations we conclude that in within the limitations of such a study, ERß seems to be a more important player in ER $\alpha$ positive but also in ER $\alpha$ negative breast cancer, irrespective of the reason for this negativity (Tam induced or epigenetically mediated i.e. by ER $\alpha$ promoter methylation). The observation of ERß and Vim3 positive tumor parallel our results from the cell culture study suggesting that the translocation of ET-1 into the nucleus via ERß is responsible for the overproduction of Vim3, which may well be important for cells to lose their anchorage, and leave the cell layer. 
Further support for our concept can be drawn from observations in the literature regarding the role for estrogens and ET- 1 in female genital organs such as the uterus [47], and the ovary [48], where interactions with Tam have been studied in respective tumors. Williams-Brown and her team showed in 2011 [49] that Tam increases the risk of endometrial cancer by altering the estrogen metabolism in endometrial cells. ET-1 has also been found as a mediator of invasiveness, neovascularization and promotes proliferation by acting as an antiapoptotic factor in ovarian tumors [48]. Our findings that ET-1 triggers its pro-invasive transcriptional and translational effects through the ER $\alpha$ and $\operatorname{ER} \beta$ could be an explanation for the increased risk of endometrial cancer associated with Tam therapy.

The extensive use of Tam in the last three decades [50] in adjuvant therapy for breast cancer has been solely based on the presence of ER $\alpha$ [51]. Problems have emerged in therapeutic efficiency regarding this concept: a de novo resistance in as much as $50 \%$ of patients [40], and the development of a relapse in the initial positive response [52]. In addition, the discovery of ERß in 1996 did not lead to the recognition of the interaction of Tam with the ER type in order to understand how it triggers the agonistic or antagonistic effects in breast cancer. Since we describe that the complex of ER $\beta$, Tam and ET-1 triggers a pro-invasive gene response and an increased uptake of ET-1, it seems likely that the presence of $\mathrm{ER} \beta$ suppresses the positive effect of Tam on ER $\alpha$ positive breast cancer patients [45]. Thus we propose to test breast cancer patients not only for ER $\alpha$ but also for $\mathrm{ER} \beta$ when increased levels of ET-1 are found together with ERß expression. Alternative treatment options for Tam should be considered, since the complex formation and subsequent activation of a specific pro-invasive gene response seem likely. In this respect, future studies unraveling the mystery of the mechanism behind the switch in the signaling cascade between ER $\alpha$ and ERß after Tam treatment may provide new treatment options. Further clinical-histological studies evaluating this new concept are needed to substantiate our findings and their long term implications. However, knowing of the existence of the ER switch in signaling after Tam in breast cancer patients with elevated ET-1 levels is an important further step for an individualized therapy, particularly in Tam resistance.

\section{Acknowledgements}

This project was supported by Koeln Fortune Program/Faculty of Medicine, University of Cologne and excellence cluster initiative supported by University of Cologne and DFG. We gratefully acknowledge receiving excellent technical support in the preparation of the biopsy and mastectomy sections (Mrs. Beate Rygol), in immunohistology (Mrs. Marion Müller), and in tissue array techniques (Mrs. Magdalene Fielenbach).

\section{References}

[1] Jemal, A., Bray, F., Center, M.M., Ferlay, J., Ward, E. and Forman, D. (2011) Global 
Cancer Statistics Tics. CA: A Cancer Journal for Clinicians, 61, 69-90. https://doi.org/10.3322/caac.20107

[2] Gruvberger-Saal, S.K., Bendahl, P.O., Saal, L.H., Laakso, M., Hegardt, C., Eden, P., Peterson, M.P., Isola, J., Borg, A., et al. (2007) Estrogen Receptor Beta Expression Is Associated with Tamoxifen Response in Eralpha-Negative Breast Carcinoma. Clinical Cancer Research, 13, 1987-1994. https://doi.org/10.1158/1078-0432.CCR-06-1823

[3] Jensen, E.V., Desombre, E.R., Kawashima, T., Suzuki, T., Kyser, K. and Jungblut, P.W. (1967) Estrogen-Binding Substances of Target Tissues. Science, 158, 529-530. https://doi.org/10.1126/science.158.3800.529-c

[4] Mosselman, S., Polman, J. and Dijkema, R. (1996) ER Beta: Identification and Characterization of a Novel Human Estrogen Receptor. FEBS Letters, 392, 49-53. https://doi.org/10.1016/0014-5793(96)00782-X

[5] Litwiniuk, M.M., Roznowski, K., Filas, V., Godlewski, D.D., Stawicka, M., Kaleta, R. and Breborowicz, J. (2008) Expression of Estrogen Receptor Beta in the Breast Carcinoma of BRCA1 Mutation Carriers. BMC Cancer, 8, 100.

https://doi.org/10.1186/1471-2407-8-100

[6] Hopp, T.A., Weiss, H.L., Parra, I.S., Cui, Y., Osborne, C.K. and Fuqua, S.A. (2004) Low Levels of Estrogen Receptor Beta Protein Predict Resistance to Tamoxifen Therapy in Breast Cancer. Clinical Cancer Research, 10, 7490-7499. https://doi.org/10.1158/1078-0432.CCR-04-1114

[7] Yan, Y., Li, X., Blanchard, A., Bramwell, V.H., Pritchard, K.I., Tu, D., Shepherd, L., Myal, Y., Penner, C., Watson, P.H., et al. (2013) Expression of Both Estrogen Receptor-Beta 1 (ER-beta1) and Its Co-Regulator Steroid Receptor RNA Activator Protein (SRAP) Are Predictive for Benefit from Tamoxifen Therapy in Patients with Estrogen Receptor-Alpha (ER-alpha)-Negative Early Breast Cancer (EBC). Annals of Oncology, 24, 1986-1993. https://doi.org/10.1093/annonc/mdt132

[8] Younes, M. and Honma, N. (2011) Estrogen Receptor Beta. Archives of Pathology \& Laboratory Medicine, 135, 63-66.

[9] Murphy, L.C., Leygue, E., Niu, Y., Snell, L., Ho, S.M. and Watson, P.H. (2002) Relationship of Coregulator and Oestrogen Receptor Isoform Expression to De Novo Tamoxifen Resistance in Human Breast Cancer. British Journal of Cancer, 87, 1411-1416. https://doi.org/10.1038/sj.bjc.6600654

[10] Novelli, F., Milella, M., Melucci, E., Di Benedetto, A., Sperduti, I., Perrone-Donnorso, R., Perracchio, L., Venturo, I., Nistico, C., Fabi, A., et al. (2008) A Divergent Role for Estrogen Receptor-Beta in Node-Positive and Node-Negative Breast Cancer Classified According to Molecular Subtypes: An Observational Prospective Study. Breast Cancer Research, 10, R74.

https://doi.org/10.1186/bcr2139

[11] Kojima, K. and Nihei, Z. (1995) Expression of Endothelin-1 Immunoreactivity in Breast Cancer. Surgical Oncology, 4, 309-315. https://doi.org/10.1016/S0960-7404(10)80043-X

[12] Matteucci, E., Maroni, P., Luzzati, A., Perrucchini, G., Bendinelli, P. and Desiderio, M.A. (2013) Bone Metastatic Process of Breast Cancer Involves Methylation State Affecting E-Cadherin Expression through TAZ and WWOX Nuclear Effectors. European Journal of Cancer, 49, 231-244. https://doi.org/10.1016/j.ejca.2012.05.006

[13] Tamkus, D., Sikorskii, A., Gallo, K.A., Wiese, D.A., Leece, C., Madhukar, B.V., Chivu, S.C., Chitneni, S. and Dimitrov, N.V. (2013) Endothelin-1 Enriched Tumor Phenotype Predicts Breast Cancer Recurrence. ISRN Oncology, 2013, Article ID: 
385398. https://doi.org/10.1155/2013/385398

[14] Yanagisawa, M., Kurihara, H., Kimura, S., Goto, K. and Masaki, T. (1988) A Novel Peptide Vasoconstrictor, Endothelin, Is Produced by Vascular Endothelium and Modulates Smooth Muscle Ca ${ }^{2+}$ Channels. Journal of Hypertension, 6, S188-S191. https://doi.org/10.1097/00004872-198812040-00056

[15] Irani, S., Salajegheh, A., Smith, R.A. and Lam, A.K. (2014) A Review of the Profile of Endothelin Axis in Cancer and Its Management. Critical Reviews in Oncologyl Hematology, 89, 314-321. https://doi.org/10.1016/j.critrevonc.2013.08.011

[16] McKenzie, G.A., Hinsley, E.E., Hunter, K. and Lambert, D.W. (2104) The Endothelin Axis in Head and Neck Cancer: A Promising Therapeutic Opportunity? Journal of Oral Pathology \& Medicine, 43, 395-404.

[17] Rosano, L., Spinella, F. and Bagnato, A. (2013) Endothelin 1 in Cancer: Biological Implications and Therapeutic Opportunities. Nature Reviews Cancer, 13, 637-651. https://doi.org/10.1038/nrc3546

[18] Liakou, P., Tepetes, K., Germenis, A., Leventaki, V., Atsaves, V., Patsouris, E., Roidis, N., Hatzitheophilou, K. and Rassidakis, G.Z. (2012) Expression Patterns of Endothelin-1 and Its Receptors in Colorectal Cancer. Journal of Surgical Oncology, 105, 643-649. https://doi.org/10.1002/jso.23017

[19] Montironi, R., Mazzucchelli, R., Barbisan, F., Stramazzotti, D., Santinelli, A., Lopez Beltran, A., Cheng, L., Montorsi, F. and Scarpelli, M. (2007) Immunohistochemical Expression of Endothelin-1 and Endothelin-A and Endothelin-B Receptors in High-Grade Prostatic Intraepithelial Neoplasia and Prostate Cancer. European Urology, 52, 1682-1689. https://doi.org/10.1016/j.eururo.2007.02.024

[20] Wang, Q.B., Qu, W.S., Qin, D.S. and Wang, Z.P. (2006) Roles of Endothelin and Its Receptors in Prostate Cancer. National Journal of Andrology, 12, 450-452.

[21] Wulfing, C., Eltze, E., Piechota, H., Abol-Enein, H., Wulfing, P., Bode, M.E., Hertle, L. and Sievert, K.D. (2005) Expression of Endothelin-1 and Endothelin-A and -B Receptors in Invasive Bladder Cancer. Oncology Reports, 13, 223-228.

[22] Alanen, K., Deng, D.X. and Chakrabarti, S. (2000) Augmented Expression of Endothelin-1, Endothelin-3 and the Endothelin-B Receptor in Breast Carcinoma. Histopathology, 36, 161-167. https://doi.org/10.1046/j.1365-2559.2000.00795.x

[23] Wulfing, P., Diallo, R., Kersting, C., Wulfing, C., Poremba, C., Rody, A., Greb, R.R., Bocker, W. and Kiesel, L. (2003) Expression of Endothelin-1, Endothelin-A, and Endothelin-B Receptor in Human Breast Cancer and Correlation with Long-Term Follow-Up. Clinical Cancer Research, 9, 4125-4131.

[24] Grimshaw, M.J. (2005) Endothelins in Breast Tumour Cell Invasion. Cancer Letters, 222, 129-138. https://doi.org/10.1016/j.canlet.2004.08.029

[25] Namazi, S., Rouhani Fard, S.A. and Abedtash, H. (2008) Role of Endothelin-1 in Tamoxifen Resistance: Mechanism for a New Possible Treatment Strategy in Breast Cancer. Medical Hypotheses, 70, 109-111. https://doi.org/10.1016/j.mehy.2007.01.092

[26] von Brandenstein, M.G., Ngum Abety, A., Depping, R., Roth, T., Koehler, M., Dienes, H.P. and Fries, J.W. (2008) A p38-p65 Transcription Complex Induced by Endothelin-1 Mediates Signal Transduction in Cancer Cells. Biochimica et Biophysica Acta, 1783, 1613-1622. https://doi.org/10.1016/j.bbamcr.2008.04.003

[27] von Brandenstein, M., Depping, R., Schafer, E., Dienes, H.P. and Fries, J.W. (2011) Protein Kinase C Alpha Regulates Nuclear Pri-microRNA 15a Release as Part of 
Endothelin Signaling. Biochimica et Biophysica Acta, 1813, 1793-1802. https://doi.org/10.1016/j.bbamcr.2011.06.006

[28] von Brandenstein, M., Puetz, K., Schlosser, M., Löser, M., Kallinowski, J.P., Gödde, D., Buettner, R., Störkel, S. and Fries, J.W.U. (2015) Vimentin 3-The New Hope-Differentiating RCC vs. Oncocytoma. Disease Markers, 2015, Article ID: 368534.

[29] Sweeney, E.E., McDaniel, R.E., Maximov, P.Y., Fan, P. and Jordan, V.C. (2012) Models and Mechanisms of Acquired Antihormone Resistance in Breast Cancer. Significant Clinical Progress despite Limitations. Hormone Molecular Biology and Clinical Investigation, 9, 143-163.

[30] Mehta, P.P., Whalen, P., Baxi, S.M., Kung, P.P., Yamazaki, S. and Yin, M.J. (2011) Effective Targeting of Triple-Negative Breast Cancer Cells by PF-4942847, Anovel Oral Inhibitor of Hsp 90. Clinical Cancer Research, 17, 5432-5442. https://doi.org/10.1158/1078-0432.CCR-11-0592

[31] Lee, Y.H., Kang, B.S. and Bae, Y.S. (2014) Premature Senescence in Human Breast Cancer and Colon Cancer Cells by Tamoxifen-Mediated Reactive Oxygen Species Generation. Life Sciences, 97, 116-122. https://doi.org/10.1016/j.lfs.2013.12.009

[32] Lukášová, E., Kovařík, A. and Kozubek, S. (2018) Consequences of Lamin B1 and Lamin B Receptor Downregulation in Senescence. Cell, 7, E11.

[33] Bagnato, D., Salani, D., Castro, V., Wu-Wong, J., Nicotra, M., Venuti, A. and Natali, P.G. (1999) Expression of Endothelin 1 and Endothelin A Receptor in Ovarian Carcinoma. Evidence for an Autocrine Role in Tumor Growth. Cancer Research, 59, 720-727.

[34] Schafer, Z.T. and Brugge, J.S. (2007) IL-6 Involvement in Epithelial Cancers. Journal of Clinical Investigation, 117, 3660-3663. https://doi.org/10.1172/JCI34237

[35] Ibrahim, S.A., El-Ghonaimy, E.A., Hassan, H., Mahana, N., Mahmoud, M.A., El-Mamlouk, T., El-Shinawi, M. and Mohamed, M.M. (2016) Hormonal-Receptor Positive Breast Cancer: IL-6 Augments Invasion and Lymph Node Metastasis via Stimulating Cathepsin B Expression. Journal of Advanced Research, 7, 661-670. https://doi.org/10.1016/j.jare.2016.06.007

[36] Jessen, J.R. (2009) Noncanonical Wnt Signaling in Tumor Progression and Metastasis. Zebrafish, 6, 21-28. https://doi.org/10.1089/zeb.2008.0571

[37] Uysal-Onganer, P., Kawano, Y., Caro, M., Walker, M.M., Diez, S., Darrington, R.S., Waxman, J. and Kypta, R.M. (2010) Wnt-11 Promotes Neuroendocrine-Like Differentiation, Survival and Migration of Prostate Cancer Cells. Molecular Cancer Therapeutics, 9, 55. https://doi.org/10.1186/1476-4598-9-55

[38] Dwyer, M., Joseph, J., Wade, H., Eaton, M., Kunder, R.S., Kazmin, D., Chang, C. and McDonnell, D.P. (2010) WNT11 Expression Is Induced by Estrogen-Related Receptor Alpha and Beta-Catenin and Acts in an Autocrine Manner Toincrease Cancer Cell Migration. Cancer Research, 70, 9298-9308. https://doi.org/10.1158/0008-5472.CAN-10-0226

[39] Luga, V., Zhang, L., Viloria-Petit, A.M., Ogunjimi, A.A., Inanlou, M.R., Chiu, E., Buchanan, M., Hosein, A.N., Basik, M. and Wrana, J.L. (2012) Exosomes Mediate Stromal Mobilization of Autocrine Wnt-PCP Signaling in Breast Cancer Cell Migration. Cell, 151, 1542-1556. https://doi.org/10.1016/j.cell.2012.11.024

[40] Ring, A. and Dowsett, M. (2004) Mechanisms of Tamoxifen Resistance. Endocrine-Related Cancer, 11, 643-658. https://doi.org/10.1677/erc.1.00776

[41] Thakkar, D., Shervington, L. and Shervington, A. (2011) Proteomic Studies Coupled 
with RNAi Methodologies Can Shed Further Light on the Downstream Effects of Telomerase in Glioma. Cancer Investigation, 29, 113-122. https://doi.org/10.3109/07357907.2010.543212

[42] Otsuki, S., Inokuchi, M., Enjoji, M., Ishikawa, T., Takagi, Y., Kato, K., Yamada, H., Kojima, K. and Sugihara, K. (2011) Vimentin Expression Is Associated with Decreased Survival in Gastric Cancer. Oncology Reports, 25, 1235-1242.

[43] Speirs, V., Parkes, A.T., Kerin, M.J., Walton, D.S., Carleton, P.J., Fox, J.N. and Atkin, S.L. (1999) Coexpression of Estrogen Receptor Alpha and Beta. Poor Prognostic Factors in Human Breast Cancer? Cancer Research, 59, 525-528.

[44] Matthews, J. and Gustafsson, J.A. (2003) Estrogen Signaling. A Subtle Balance between ER Alpha and ER Beta. Molecular Interventions, 3, 281-292. https://doi.org/10.1124/mi.3.5.281

[45] Hall, J.M. and McDonnell, D.P. (1999) The Estrogen Receptor Beta-Isoform (ERbeta) of the Human Estrogen Receptor Modulates ERalpha Transcriptional Activity and Is a Key Regulator of the Cellular Response to Estrogens and Antiestrogens. Endocrinology, 140, 5566-5578.

https://doi.org/10.1210/endo.140.12.7179

[46] Grimshaw, M., Hagemann, T., Ayhan, A., Gillett, C., Binder, C. and Balkwill, F. (2004) A Role for Endothelin-2 and Its Receptors in Breast Tumor Cell Invasion. Cancer Research, 64, 2461-2468. https://doi.org/10.1158/0008-5472.CAN-03-1069

[47] Couse, J.F. and Korach, K.S. (1999) Estrogen Receptor Null Mice. What Have We Learned and Where Will They Lead Us? Endocrine Reviews, 20, 358-417. https://doi.org/10.1210/edrv.20.3.0370

[48] Rosano, L., Spinella, F. and Bagnato, A. (2010) The Importance of Endothelin Axis in Initiation, Progression, and Therapy of Ovarian Cancer. AJP Regulatory Integrative and Comparative Physiology, 299, R395-404. https://doi.org/10.1152/ajpregu.00304.2010

[49] Williams-Brown, M.Y., Salih, S.M., Xu, X., Veenstra, T.D., Saeed, M., Theiler, S.K., Diaz-Arrastia, C.R. and Salama, S.A. (2011) The Effect of Tamoxifen and Raloxifene on Estrogen Metabolism and Endometrial Cancer Risk. The Journal of Steroid Biochemistry and Molecular Biology, 126, 78-86. https://doi.org/10.1016/j.jsbmb.2011.05.001

[50] Garcia-Becerra, R., Santos, N., Diaz, L. and Camacho, J. (2013) Mechanisms of Resistance to Endocrine Therapy in Breast Cancer. Focus on Signaling Pathways, miRNAs and Genetically Based Resistance. International Journal of Molecular Sciences, 14, 108-145. https://doi.org/10.3390/ijms14010108

[51] Dahlman-Wright, K., Cavailles, V., Fuqua, S., Jordan, V., Katzenellenbogen, J., Korach, K., Maggi, A., Muramatsu, M., Parker, M. and Gustafsson, J. (2006) International Union of Pharmacology. LXIV Estrogen Receptors. Pharmacological Reviews, 58, 773-781. https://doi.org/10.1124/pr.58.4.8

[52] Gradishar, W.J. (2004) Tamoxifen-What Next? Oncologist, 9, 378-384. https://doi.org/10.1634/theoncologist.9-4-378 


\section{List of Abbreviations}

ERa: Estrogen receptor alpha;

ERß: Estrogen receptor beta;

ß-est: ß-estradiol;

ET-1: Endothelin-1;

ETAR: Endothelin A receptor;

ETBR: Endothelin B receptor;

IL-6: Interleukin-6;

IP: Immunoprecipitation;

Tam: Tamoxifen;

Vim3: Vimentin 3;

Wnt11: Wnt signaling protein 11. 